\title{
Implementation of strategies to counteract the consequences of the pandemic in the tourism sector
}

\author{
Shvets I. Yu. \\ Financial University under the Government of the Russian Federation, Moscow, Russia. \\ ORCID https://orcid.org/0000-0002-9602-9582 \\ Irina Shvets, PhD in Economics, Professor, and Moscow (E-mail: i.y.shvets@gmail.com)
}

Article History: Received: 11 January 2021; Accepted: 27 February 2021; Published online: 5 April 2021

\begin{abstract}
The purpose of the article is to analyze the implementation of strategies to mitigate the socio-economic impact of Covid19 and restore the tourism sector. Estimates at the national level are quite complex and reflect the scale of the impact on tourism, as well as the challenges associated with predicting a rapidly changing and uncertain situation. Quantifying the current and future impacts of the crisis on tourism is challenging, as the crisis has exposed weaknesses in tourism statistical information systems, including the lack of reliable, comparable and timely data to support political and business decisions. A number of forecasts presented in the spring and summer of 2020 did not come true. Forecasting the impact of the pandemic on the tourism economy is faced with a high degree of uncertainty, a rapidly changing epidemiological situation at the level of national states and regions. The article analyzes the implementation of the main strategies recommended by the UNWTO to overcome the consequences of the pandemic: 1) crisis management and mitigation; 2) providing incentives and accelerating recovery; and 3) preparing for tomorrow and developing tactics to overcome the crisis in the tourism sector using the example of the countries analyzed. The recovery of tourism will depend on the interrelated effects of the economic crisis and the health crisis on overcoming the pandemic, the influence of supply and demand factors. The peculiarity of the current crisis lies in the global nature of its scale, duration, continuing uncertainty and the interconnectedness of economic, social and medical factors of influence.
\end{abstract}

Keywords: tourism industry, strategies, tactics, pandemic, recovery.

The Covid-19 pandemic has negatively affected many different tourism sectors, eventually leading to large restrictions, temporary suspension of activities in a number of countries and regions. Currently, it is difficult to assess the long-term economic, behavioral, or social consequences of the COVID-19 pandemic. The year of the pandemic showed that at the national socio-economic systems level, neither the state, nor the corporate sectors of the economy, nor the household sector were ready for the pandemic. As a result of strict quarantine measures, travel restrictions related to COVID-19 were imposed in most destinations around the world, which are still sectorally in effect in the sector. Although various efforts have been made to open up the industry since June 2020 , most sectors continue to struggle with the effects of the ongoing coronovirus pandemic.

Crises are a common phenomenon in tourism. Many areas have been affected by natural, man-made, political, and economic crises, and tactics and strategies have been developed over the years to ensure sustainability and mitigate the consequences [1].

However, the crisis caused by the Covid-19 pandemic was different and unique in many ways. First, the decline in travel, hospitality and tourism is observed all over the world. Secondly, the ongoing crisis may cause fundamental changes in many tourism segments. Also, due to the complexity of predicting the pandemic development, it is difficult to predict the future state and development of the tourism sector.

Since the introduction of the quarantine, millions of jobs in the global tourism sector and related industries have been lost due to the cancellation of tours, flights, events and hotels. In taking these measures, Governments around the world have sought to find a balance between maintaining their economies and preventing dangerous levels of unemployment and deprivation. They were trying to respond to public health opportunities to prevent the collapse of health systems and mass deaths.

Today, as the Covid-19 pandemic continues, the government and the corporate sector of the economy are wondering: how severe will the Covid-19 recession be; what will be the growth and recovery scenarios, and whether there will be any long-term structural impact from the unfolding crisis.

A review of the current literature about the impact of Covid-19 on the tourism industry shows that most of currently published studies are attempts to analyze the effects of COVID-19, its impact on tourism, studies of influence factors, threats, and trends of the survival of the tourism sphere $[2,3,4,5]$. Interesting are the works 
using the empirical method devoted to the dynamic stochastic modeling of the general equilibrium of the coronavirus pandemic outbreak and the state of the tourism sector. [6].

The UNWTO research note examines the adoption of these policies in national recovery plans and examines their limitations as evidence-based policies. The UNWTO Policy on supporting jobs and the economy through travel and tourism, first published in April 2020, includes a call for action to mitigate the socio-economic impact of Covid-19 and accelerate recovery [7].

Despite the fact that the consequences of COVID-19 over the past year have been analyzed by many researchers, its global and local impact on the tourism sector is unprecedented, the large-scale development of the pandemic pushes for further research on the formation of state tourism development policies based on strategic planning.

The purpose of the article is to analyze the implementation of strategies to mitigate the socio-economic impact of Covid-19 and restore the tourism sector.

The contribution of tourism to the world economy in 2019 amounted to $10.9 \%$ of GDP and about $30 \%$ of exports. Due to the peculiarities of providing tourist services, every tenth workplace was associated with the tourism industry, having a significant impact on the development of related industries. In the Russian economy, 53 industries can be identified that are integratively related to the tourism sector, which also contributed to the economy diversification.

According to the United Nations World Tourism Organization, as of October 2020, 100\% of destinations worldwide had travel restrictions related to Covid-19. According to the World Tourism Organization, the number of international arrivals decreased by $70 \%$ in the first eight months of 2020 . The most significant decline in international arrivals in January - April 2020 was observed in the Asia-Pacific region (51\%), followed by Europe (44\%) and the Middle East (40\%). The decrease in the number of international arrivals in America and Africa was 36 and $35 \%$, respectively.

Losses in this regard amounted to $\$ 730$ billion, it is noted that this is more than eight times higher than the losses the sector suffered in 2009 due to the global economic and financial crisis. The pandemic has significantly affected every sector of the tourism: travel agencies, tour operators, online travel organizations, hotels, restaurants, transport, cruise lines, etc.. Due to the fact that the majority of enterprises in the sphere are represented by small and medium-sized enterprises included in the large informal tourism sector, many of them may not survive the crisis without significant support. Due to the peculiarities of the tourist services provision, this has led to a chain reaction throughout the tourist supply chain, affecting trade, agriculture and other industries.

According to the World Bank's forecast, global GDP will shrink by 5.21\% in 2020 (the decline in 2019 was $2.38 \%$ ) and will grow by $4.16 \%$ in 2021. The dynamics of the decline in Russia's GDP in 2020 will be $6 \%$ (compared to the growth of $1.3 \%$ in 2019), and then, according to estimates, by $1.3 \%$ in 2021.

In 2019, the direct, indirect, and multiplier effects of travel and tourism accounted for $10.3 \%$ of global GDP (US \$ 8.9 trillion) and 330 million jobs, or 1 in 10 jobs worldwide. As a result of the COVID-19 pandemic, the global travel and tourism market is projected to lose 121 million jobs worldwide and $\$ 3,435$ billion in global GDP in 2020 .

In early May 2020, UNWTO presented three possible scenarios for the tourism sector development, which indicate a potential reduction in the total number of international tourists from 58 to $78 \%$, depending on when the travel restrictions are lifted [8]. Since mid-May, UNWTO has identified an increase in the number of destinations announcing measures to resume tourism. These include the introduction of enhanced safety and hygiene measures, as well as policies aimed at developing domestic tourism.

Strategies and tactics recommended by UNWTO were used to analyze the national plans. Three main strategies are presented: 1) crisis management and mitigation; 2) providing incentives and accelerating recovery; and 3) preparing for tomorrow and 23 tactics to overcome the crisis in the tourism sector. Six countries were selected for the analysis.

Table 1

\begin{tabular}{|l|l|l|l|l|}
\hline & $\begin{array}{l}\text { Tourism as \% of } \\
\text { GDP (direct } \\
\text { contribution) } \\
(2019)\end{array}$ & $\begin{array}{l}\text { Population, } \\
\text { million people }\end{array}$ & $\begin{array}{l}\text { Number of } \\
\text { confirmed cases / } \\
\text { deaths (October } \\
2020)\end{array}$ & $\begin{array}{l}\text { Launch of national } \\
\text { preventive measures } \\
\text { against the COVID-19 } \\
\text { pandemic }\end{array}$ \\
\hline Russia & 3,4 & 146 & $1636781 / 78632$ & March 2020 \\
\hline
\end{tabular}




\begin{tabular}{|l|l|l|l|l|}
\hline Germany & 3,9 & 83,02 & $986394 / 14586$ & March 2020 \\
\hline China & 3,4 & 1400,9 & $85470 / 4634$ & January 2020 \\
& & & & \\
\hline Canada & 2 & 37,5 & $201437 / 9778$ & March 2020 \\
\hline Italy & 5,5 & 60,5 & $1028424 / 42953$ & February 2020 \\
\hline Israel & 2,5 & 9,4 & $280000 / 2538$ & March 2020 \\
\hline Spain & 5,4 & 46,07 & $11329712 / 35031$ & February 2020 \\
\hline USA & 3,7 & 328,2 & $8632814 / 224601$ & March 2020 \\
& & & & \\
\hline Turkey & 3,8 & 82 & $349519 / 9371$ & April 2020 \\
\hline France & 3,6 & 66,99 & $1891233 / 44054$ & February 2020 \\
\hline Japan & 1,7 & 126 & $180815 / 1813$ & February 2020 \\
\hline
\end{tabular}

Sources: 9, 11, 12, 15, 16 .

The eleven countries surveyed were selected based on geographical distribution, pandemic stages, size and shape, past historical crises, and border status. The information is based on each country's UNWTO reports on its national tourism policy and national reports. Each country's national recovery plan was analyzed according to UNWTO strategies and tactics, indicating whether the plan met the criteria: using yes/no ranking, partially implemented by category. Both the UNWTO recommendations and the current national tourism strategies of each country were reviewed.

Table 2

\begin{tabular}{|c|c|c|c|}
\hline & $\begin{array}{l}\text { First UNWTO strategy: } \\
\text { "Crisis management and } \\
\text { mitigation" }\end{array}$ & $\begin{array}{l}\text { Second UNWTO strategy: } \\
\text { "Providing incentives and } \\
\text { accelerating recovery" }\end{array}$ & $\begin{array}{l}\text { Third UNWTO strategy: } \\
\text { "Preparing for tomorrow" }\end{array}$ \\
\hline Employment & $\begin{array}{l}\text { 1.1. Promoting job } \\
\text { retention, supporting the } \\
\text { self-employed and } \\
\text { protecting the most } \\
\text { vulnerable groups } \\
\text { Russia-partially } \\
\text { China no } \\
\text { Germany-partially } \\
\text { Canada-partially } \\
\text { Italy-yes } \\
\text { Israel-partially } \\
\text { Spain-partially } \\
\text { USA-partially } \\
\text { Turkey-no } \\
\text { France-partially } \\
\text { Japan-partially }\end{array}$ & & \\
\hline Financial assistance & $\begin{array}{l}1.2 . \quad \text { Maintaining } \\
\text { companies` liquidity } \\
\text { Russia-partially } \\
\text { Germany-partially } \\
\text { China no } \\
\text { Canada-partially } \\
\text { Italy-partially } \\
\text { Israel-partially } \\
\text { Spain-partially } \\
\text { USA-partially } \\
\text { Turkey-partially } \\
\text { France-partially }\end{array}$ & $\begin{array}{l}\text { 2.1. Introducing financial } \\
\text { incentives for investment } \\
\text { in tourism and } \\
\text { operational activities } \\
\text { Russia-no } \\
\text { Germany-no } \\
\text { China-no } \\
\text { Canada-no } \\
\text { Italy-no } \\
\text { Israel-no } \\
\text { Spain-no } \\
\text { USA-no }\end{array}$ & \\
\hline
\end{tabular}




\begin{tabular}{|c|c|c|c|}
\hline & Japan-partially & $\begin{array}{l}\text { Turkey-no } \\
\text { France-no } \\
\text { Japan-no }\end{array}$ & \\
\hline Regulatory measures & $\begin{array}{l}\text { 1.3. Checking taxes, fees, } \\
\text { fees and regulations } \\
\text { affecting transport and } \\
\text { tourism } \\
\text { Russia-partially } \\
\text { Germany-partially } \\
\text { China-partially } \\
\text { Canada-partially } \\
\text { Italy-yes } \\
\text { Israel-partially } \\
\text { Spain-yes } \\
\text { USA-partially } \\
\text { Turkey-partially } \\
\text { France-partially } \\
\text { Japan-no }\end{array}$ & $\begin{array}{l}\text { 2.2. Checking taxes, fees, } \\
\text { fees and regulations } \\
\text { affecting travel and } \\
\text { tourism } \\
\text { Russia-partially } \\
\text { Germany-partially } \\
\text { China-partially } \\
\text { Canada-partially } \\
\text { Italy-yes } \\
\text { Israel-partially } \\
\text { Spain-yes } \\
\text { USA-partially } \\
\text { Turkey-partially } \\
\text { France-partially } \\
\text { Japan-no }\end{array}$ & \\
\hline $\begin{array}{l}\text { Including in emergency } \\
\text { care packages }\end{array}$ & $\begin{array}{l}\text { 1.4. Including tourism in } \\
\text { national, regional and } \\
\text { international economic } \\
\text { emergency packages } \\
\text { Russia-partly by category } \\
\text { Germany-no } \\
\text { China-partly by category } \\
\text { Canada-no } \\
\text { Italy-no } \\
\text { Israel-no } \\
\text { Spain-no } \\
\text { USA-no } \\
\text { Turkey-no } \\
\text { France-no } \\
\text { Japan-yes }\end{array}$ & $\begin{array}{l}\text { 2.3. Tourism in national } \\
\text { and regional recovery } \\
\text { programs, development } \\
\text { assistance } \\
\text { Russia-yes } \\
\text { Germany-yes } \\
\text { China-no } \\
\text { Canada-no } \\
\text { Italy-yes } \\
\text { Israel-no } \\
\text { Spain-yes } \\
\text { USA-no } \\
\text { Turkey-yes } \\
\text { France-yes } \\
\text { Japan-no }\end{array}$ & $\begin{array}{l}\text { 3.1. Preparing for the } \\
\text { crisis, building resilience } \\
\text { and ensuring that tourism } \\
\text { is part of the national } \\
\text { emergency mechanism } \\
\text { and system } \\
\text { Russia-no } \\
\text { Germany-no } \\
\text { China-no } \\
\text { Canada-no } \\
\text { Italy-no } \\
\text { Israel-no } \\
\text { Spain-no } \\
\text { USA-no } \\
\text { Turkey-no } \\
\text { France-no } \\
\text { Japan-no }\end{array}$ \\
\hline Human capital & $\begin{array}{l}\text { 1.5. Promoting } \\
\text { development of skills, } \\
\text { especially digital skills } \\
\text { Russia-no } \\
\text { Germany-no } \\
\text { China-no } \\
\text { Canada-no } \\
\text { Italy-no } \\
\text { Israel-no } \\
\text { Spain-no } \\
\text { USA-no } \\
\text { Turkey-no } \\
\text { France-no } \\
\text { Japan-no }\end{array}$ & $\begin{array}{l}\text { 2.4. Promoting new jobs } \\
\text { and development skills, } \\
\text { especially in the digital } \\
\text { sphere } \\
\text { Russia-no } \\
\text { Germany-no } \\
\text { China-no } \\
\text { Canada-no } \\
\text { Italy-no } \\
\text { Israel-no } \\
\text { Germany } \\
\text { Spain-no } \\
\text { USA-no } \\
\text { Turkey-no } \\
\text { France-no } \\
\text { Japan-no }\end{array}$ & $\begin{array}{l}\text { 3.2. Investments in } \\
\text { human capital and its } \\
\text { development } \\
\text { Russia-no } \\
\text { China-no } \\
\text { Canada-no } \\
\text { Germany-no } \\
\text { Italy-yes } \\
\text { Israel-no } \\
\text { Japan-no } \\
\text { Spain-no } \\
\text { USA-no } \\
\text { Turkey-no } \\
\text { France-no }\end{array}$ \\
\hline
\end{tabular}




\begin{tabular}{|c|c|c|c|}
\hline Government & $\begin{array}{lr}\begin{array}{l}\text { 1.6. Forming } \\
\text { management }\end{array} & \text { crisis } \\
\text { strategies } & \text { and } \\
\text { Russia-partially } & \\
\text { Germany-partially } & \\
\text { China-no } & \\
\text { Canada-partially } & \\
\text { Italy-partly } & \\
\text { Israel-partially } & \\
\text { Spain-partly } & \\
\text { USA-partially } & \\
\text { Turkey-partially } & \\
\text { France-partly } & \\
\text { Japan-partially }\end{array}$ & & $\begin{array}{l}\text { 3.3. Strengthening } \\
\text { tourism management at } \\
\text { all levels } \\
\text { Russia-partly by category } \\
\text { Germany-no } \\
\text { China-no } \\
\text { Canada-no } \\
\text { Italy-no } \\
\text { Israel-no } \\
\text { Spain-no } \\
\text { USA-no } \\
\text { Turkey-partially } \\
\text { France-no } \\
\text { Japan-no }\end{array}$ \\
\hline Maintaining demand & $\begin{array}{l}\text { 1.7. Ensuring consumer } \\
\text { protection and trust } \\
\text { Russia-partially } \\
\text { Germany-partially } \\
\text { China-partially } \\
\text { Canada-partially } \\
\text { Italy-no } \\
\text { Israel-partially } \\
\text { Spain-no } \\
\text { USA-partially } \\
\text { Turkey-no } \\
\text { France-partly } \\
\text { Japan-partially }\end{array}$ & $\begin{array}{l}\text { 2.5. a. Advance travel } \\
\text { facilitation } \\
\text { Russia-partially } \\
\text { Germany-partially } \\
\text { China-partially } \\
\text { Canada-partially } \\
\text { Italy-yes } \\
\text { Israel-partially } \\
\text { Spain-yes } \\
\text { USA-partially } \\
\text { Turkey-yes } \\
\text { France-partially } \\
\text { Japan-partially } \\
\text { 2.5. b. Speed up } \\
\text { marketing, } \\
\text { meetings } \\
\text { Russia-no } \\
\text { Germany-no } \\
\text { China-partially } \\
\text { category } \\
\text { Canada-no } \\
\text { Italy-no } \\
\text { Israel-no } \\
\text { Spain-no } \\
\text { USA-no } \\
\text { Turkey-no } \\
\text { France-no } \\
\text { Japan-no }\end{array}$ & $\begin{array}{l}\text { 3.4. Market, product and } \\
\text { service diversification } \\
\text { Russia-no } \\
\text { Germany-no } \\
\text { China-no } \\
\text { Canada-no } \\
\text { Italy-no } \\
\text { Israel-no } \\
\text { Spain-no } \\
\text { USA-no } \\
\text { Turkey-no } \\
\text { France-no } \\
\text { Japan-no }\end{array}$ \\
\hline $\begin{array}{l}\text { Plans for development } \\
\text { stabilization }\end{array}$ & & $\begin{array}{l}2.6 . \quad \text { Focus on } \\
\text { environmental } \\
\text { sustainability in } \\
\text { incentives and assistance } \\
\text { packages } \\
\text { Russia-no } \\
\text { Germany-no } \\
\text { China-no } \\
\text { Canada-no } \\
\text { Italy-no }\end{array}$ & $\begin{array}{l}\text { 3.5. Putting sustainable } \\
\text { tourism on the national } \\
\text { agenda } \\
\text { Russia-partially } \\
\text { category } \\
\text { Germany-no } \\
\text { China-no } \\
\text { Canada-no } \\
\text { Italy-no } \\
\text { Israel-no }\end{array}$ \\
\hline
\end{tabular}




\begin{tabular}{|c|c|c|}
\hline & $\begin{array}{l}\text { Israel-no } \\
\text { Spain-no } \\
\text { USA-no } \\
\text { Turkey-no } \\
\text { France-no } \\
\text { Japan-no }\end{array}$ & $\begin{array}{l}\text { Spain-no } \\
\text { USA-no } \\
\text { Turkey-no } \\
\text { France-no } \\
\text { Japan-no }\end{array}$ \\
\hline Marketing strategy & $\begin{array}{l}\text { 2.7. Understanding the } \\
\text { market and acting quickly } \\
\text { to restore confidence and } \\
\text { stimulate demand } \\
\text { Russia-no } \\
\text { Germany-no } \\
\text { China-partially } \\
\text { Canada-no } \\
\text { Italy-yes } \\
\text { Israel-no } \\
\text { Spain-yes } \\
\text { USA-no } \\
\text { Turkey-yes } \\
\text { France-no } \\
\text { Japan-yes }\end{array}$ & $\begin{array}{l}\text { 3.6. Investments in the } \\
\text { security systems market } \\
\text { and digital transformation } \\
\text { Russia-no } \\
\text { Germany-no } \\
\text { Canada-no } \\
\text { China-no } \\
\text { Italy-no } \\
\text { Israel-no } \\
\text { Spain-no } \\
\text { USA-no } \\
\text { Turkey-no } \\
\text { France-no } \\
\text { Japan-no }\end{array}$ \\
\hline $\begin{array}{l}\text { Partnerships for } \\
\text { sustainable development }\end{array}$ & $\begin{array}{l}2.8 . \quad \text { Investment in } \\
\text { partnerships } \\
\text { Russia-no } \\
\text { Germany-no } \\
\text { China-no } \\
\text { Canada-no } \\
\text { Italy-no } \\
\text { Israel-no } \\
\text { Spain-no } \\
\text { USA-no } \\
\text { Turkey-no } \\
\text { France-no } \\
\text { Japan-no }\end{array}$ & $\begin{array}{l}\text { 3.7. Transition to a } \\
\text { closed-loop economy and } \\
\text { adopting sustainable } \\
\text { development } \\
\text { Russia-no } \\
\text { Germany-no } \\
\text { China-no } \\
\text { Canada-no } \\
\text { Italy-no } \\
\text { Israel-no } \\
\text { Spain-no } \\
\text { USA-no } \\
\text { Turkey-no } \\
\text { France-no } \\
\text { Japan-no }\end{array}$ \\
\hline
\end{tabular}

Sources: $7,8,9,10,11,12,13,14,15,16$.

The results of analyzing the country implementation of the strategy to counter the effects of the pandemic in the tourism sector show a different approach to the adoption of these three UNWTO strategies at the national level. The first UNWTO strategy, "Crisis Management and Mitigation", was partially adopted by Governments in the countries analyzed. The Italian Government fully adopted two of the seven UNWTO tactics. Spain and Japan only accepted one. Israel and China did not accept any at all. Russia partially adopted six tactics out of seven.

The most widely used UNWTO tactics at the country level were the following:

1.1 - " Stimulating and preserving jobs, supporting the self-employed and protecting the most vulnerable groups»;

1.2 - "Support the liquidity of the companies." Each of these tactics was fully adopted by two countries and partially by four other countries.

As for the second UNWTO strategy, "Providing incentives and accelerating recovery", the analysis showed that it was partially adopted by the Governments in the analyzed countries. The Italian government implemented four tactics out of nine. In Russia and Japan, the governments implemented one each. In China, the government partially adopted four tactics, while the Canadian and Israeli governments partially implemented only two tactics. 
It can be stated that of the second UNWTO strategy "Providing incentives and accelerating recovery", only two tactics were implemented: Tactics 2.2 ("checking taxes, fees and regulations affecting travel and tourism") and 2.5.a ("advance travel facilitation") were adopted in whole or in part by eleven countries.

After analyzing the measures taken by the governments of eleven countries to counteract the impact of the pandemic in the tourism sector, it can be seen that the third UNWTO strategy "Preparing for Tomorrow" has not yet been implemented since nine countries have not adopted any of the recommendations. The Italian government adopted only one of the seven tactics - 3.2: "Investing in human capital and talent development by preserving jobs." The Russian government and the "Rosturizm" national agency partially implemented the tactic 3.5. "Putting sustainable tourism on the national agenda". As for the other five tactics of the third strategy, they were not adopted by the Governments of the countries.

Based in the analysis conducted, it can be argued that the Italian government and the professional community in the field of tourism and hospitality have adopted and implemented the most recommendations: seven of the 23 were adopted in full, and one was partially adopted. The Government of Russia and the professional community in the field of tourism and hospitality adopted and implemented one tactic in full and nine tactics in part. Seven tactics were adopted and partially implemented by the Governments of Germany, China, Canada, Israel, and the professional communities in the field of tourism and hospitality. In Japan, two tactics were fully implemented, five partially. In Spain, four tactics were fully implemented, while three were implemented only partially. Turkey fully implemented two tactics, and partially implemented four tactics. France fully implemented one tactic, and partially implemented seven tactics. China, Canada, Israel, and the United States have not fully implemented any of the tactics proposed by the UNWTO.

Thus, out of 253 possible recommendations - eleven countries and 23 tactics - only 20 (7.9\%) were fully implemented and only 58 were partially implemented (22.9\%). As for the third strategy, only one tactic was fully implemented by one country, Italy, and partially by the Russian government. Unfortunately, the issues of sustainable development $-3.5 ; 3.7$, human capital $-1.5 ; 2.4 ; 3.2$ and governance - $1.6 ; 3.3$ were hardly considered by the governments of countries and professional communities in the field of tourism and hospitality.

The countries included in the sample, although different in many respects, have not yet formalized comprehensive exit strategies and recovery plans for their tourism sectors, and they are currently taking various tactical measures to deal with the current crisis as part of their national tourism policies. From the complete suspension of the industry functioning and the closure of state borders to the continuation of tourist activities in the high and middle seasons. The general trend in these countries is more towards implementing short-term local solutions. The fact that no country can unilaterally make decisions on inbound and outbound tourism is due to the nature of tourism activity.

Each of the eleven countries has taken different measures at the government level and the level professional communities. This is due to a number of decisive factors, such as the impact of the pandemic, the level of morbidity, mortality, and the spread index; the level of differentiation of the economies of these countries and the share of tourism in the country's GNP; and the institutional features of the development of national models of socioeconomic systems. Most member states act alone, without applying the UNWTO strategies and recommendations.

At the same time, this sector will not become more resilient and better prepared for future crises without an international commitment to sustainable tourism. The resumption of domestic tourism will help support the tourism sector, but the real recovery will begin with the restoration of international tourism. As we can see now, the structure of tourist demand is different than we are used to, thanks to the caution of governments and tourists, and a decrease in the level of aggregate effective demand: the tourist flow largely reflects the growth of domestic tourism. The international tourist flow decreased; the duration of travel days was reduced by half.

Coordinated decisions based on risk assessment, both at the national and international levels, are important for the international tourism resumption. The UNWTO strategy "Preparing for Tomorrow" was not adopted, as countries tended to focus on local and short-term tactics for resuming tourism, putting up jobs. The third UNWTO Strategy is aimed at creating conditions and prerequisites for the long-term, sustainable development of the tourism sector. Neither national governments nor professional communities were prepared for such a large scale, the duration of the pandemic, and the measures taken in the past year were more related to crisis management. Therefore, the UNWTO Strategy "Preparing for Tomorrow" has not yet been implemented, but the tactics proposed in it are important for the sustainable recovery and development of the tourism sector in the post-pandemic period. The weakness of UNWTO tourism recovery strategies is that they are not evidence-based and provide only partial 
solutions to an international problem without a coherent international database, which is fundamentally important due to the nature of the tourist servant, the value chains in the tourism sector. Deepening mutual understanding, shared goals, and a new kind of evidence-based policy are critical requirements in rebuilding the tourism industry, both nationally and internationally, in the era of Covid-19. The policy impacts and the measures taken are highly dependent on the national institutional context. These problems create significant measurement difficulties when attempting to systematically compare national responses. A shared vision with a wide range of tactics that could be implemented in different ways would probably be more appropriate for the current time.

\section{Bibliography}

1. Ritchie B.W., Jiang Y. A review of research on tourism risk, crisis and disaster management: Launching the annals of tourism research curated collection on tourism risk, crisis and management disaster. - Annals of Tourism Research, $2019-79$.

2. Belyakova M. Yu. Impact of the Covid-19 pandemic on the state of tourism and the possibilities of its development after the end of the pandemic// Russia and the world. The world economy and international relations in the era of the multipolar world. Collection of scientific articles. Edited by O. V. Arkhipova, I. A. Klimina. St. Petersburg, 2020. pp. 14-20.

3. Muracheva M. Yu., Sesyolkin A. I. Modern problems of tourism caused by the coronavirus pandemic/ / Physical education in the conditions of the modern educational process. Collection of materials of the national scientific and practical conference. Publisher: Shuisky branch of the Federal State Budgetary Educational Institution of Higher Education "Ivanovo State University". 2020. pp. 244-247.

4. Butorov S. A. Covid-19 pandemic and its impact on the world tourism industry//Bulletin of the Moscow State University of Culture and Arts. 2020. No. 2 (94). pp. 116-125.

5. Algazina E. I., Katsiel S. A. Effect of the coronavirus pandemic on the tourism industry// Omsk Social and Humanitarian Readings-2020. Materials of the XIII International Scientific and Practical Conference. Rel. Editor: L. A. Kudrinskaya. Omsk Publishing House: Omsk State Technical University. 2020. P. 191-194.

6. Yang Y., Zang H., Chen H. Coronavirus pandemic and tourism: dynamic stochastic general equilibrium modeling of an infectious disease outbreak. Annals of Tourism Research. 2020. Jul. 83.

7. Supporting Jobs and Economies through Travel and Tourism - A Call for Action to Mitigate the SocioEconomic Impact of COVID-19 and Accelerate Recovery План преодоления экономических последствий новой коронавирусной инфекции [Электронный ресурc]: URL:https://www.unwto.org/ru/news/stepping-upsupport-and-coordination-for-a-safe-and-sustainable-recovery-of-tourism

8. Supporting jobs and the economy through travel and tourism: a call for action to mitigate the socio-economic impact of Covid-19 and accelerate recovery. UNWTO. 2020. Plan for overcoming the economic consequences of a new coronavirus infection [Electronic resource]: URL: https://www.eunwto.org/doi/book/10.18111/9789284421633.

9. Plan to overcome the economic consequences of the new coronavirus infection. UNWTO tourism data dashboard [Electronic resource]: URL:https://www.unwto.org/unwto-tourism-dashboard

10. Scenarios for the recovery of tourism and travel to 2020 and the impact on the economy of Covid-19, global data, WTTC, [Electronic resource]: June 15, 2020.

11. OECD Economic Outlook, Interim Report September 2020, [Electronic resource]: OECD Publishing, Paris, URL: https://doi.org/10.1787/34ffc900-en.

12. Analytical report: Covid-19 and the transformation of tourism [Electronic resource]: UN URL: https://unsdg.un.org/resources/policy-brief-covid-19-and-transforming-tourism

13. Restoring Tourism Competitiveness: Tourism response, recovery, and resilience to the COVID-19 crisis. [Electronic resource]: World Bank, 2020. Washington, DC. URL: https://openknowledge.worldbank.org/handle/10986/34348

14. International trade in Travel and Tourism Services: Economic Implications and Policy measures during the COVID-19 Crisis, [Electronic resource]: World Trade Organization, September 30, 2020.

15. Rosturizm Covid-19 Plan to overcome the economic consequences of a new coronavirus infection [Electronic resource]: URL:https://tourism.gov.ru/contents/covid-19/chto-nado-znat-o-koronaviruse/ 
16. Rosturizm Recommendations for the organization of work in the conditions of preserved risks of the spread of Covid-19 [Electronic resource]: URL:https://tourism.gov.ru/contents/covid-19/rekomendatsii-po-organizatsiiraboty-v-usloviyakh-sokhraneniya-riskov-rasprostraneniya-covid-19/ 